\title{
Research on the Law Guarantee System of Modern Market Economy
}

\author{
Lei $\mathrm{Yao}^{1, \mathrm{a}}$ \\ ${ }^{1}$ Cangzhou Technical College, Hebei, Cangzhou, 061001 \\ hunter2011@foxmail.com
}

Keywords: Modern Market Economy, Law Guarantee System

\begin{abstract}
Modern market economy requires two regulatory mechanisms. Civil and Commercial Law is the legal guarantee of market regulation; Ecnomic Law is the legal guarantee of national regulation. Modern market economy legal system is a huge system including a plurality of sectors law norms. For the establishment and improvement of China's market economy legal system, we should strengthen national macroeconomic regulation and control legislation, improve and perfect the microeconomic legislation. The legislation should be divided into the fundamental legislation with stability and transitional legislative. The former is the project which directly constructs market economy legal system building and the later is the construction material for the final manufacture building.
\end{abstract}

\section{The Modern Market Economy Mechanism and Its Legal Guarantee}

Market economy is a socio-economic which takes market mechanisms as a basic mechanism to adjust its structure and operation. In such a socio-economic system, market regulation is the basic factors of social resource allocation and socio-economic structure adjustment and operation.

Worldwide market economy has gone through two major stages of development from its form to now. Throughout the period of liberal capitalism, the structure and operation of social economy basically all market regulation, the law of value spontaneously and fully play a role. Few countries directly involved in economic life, participation or intervention. After the industrial revolution, since the late 19th and early 20th century, the production was highly socialized and formed the capitalist monopoly. Monopolies and unfair competition to make the law of value has been seriously distorted market regulation this "invisible hand" has been better than in the past efficacious and universal. Also look forward to the emergence of social regulatory mechanisms, in addition to the "hand" to give them assistance and cooperation in order to effectively regulate normal economic operation: a large number of countries began to intervene in economic life, social and economic intervention management. This is the state regulation, the so-called "the hand of country."[1]

Since the country was involved in economic life, social economy also needs two regulatory mechanisms of the market economy into a new development stage of the year: This is the modern market economy. Regulation of the market economy needs legal protection. Two regulatory mechanisms of modern market economy, we need to have the appropriate legal protection of its effective functioning. There are different properties of the two regulatory mechanisms, the nature and type of the legal norms of protecting its operation is not the same. Security market regulation that is "invisible hand" effective legal mechanisms operate mainly commercial law; the protection of national regulator that is, "Hand countries," the effective functioning of the legal mechanism is mainly economic law, civil and commercial law and economic law is the healthy operation of a modern market economy can not or both of legal protection mechanisms missing.

\section{The Contents Constitution of the Modern Market Economy Legal System}

Modern market economy legal system includes the following four aspects:

The legal provisions on the economic body and the socio-economic structure. To protect the normal social and economic activities, the national legal qualification of economic activity needs to establish a variety of participants, legal status, rights and obligations of their organizations and 
activities principles. And other economic entities including the main national economic management and corporate social organizations and individual citizens are basic management body. The former is responsible for a variety of economic management functions of the national authorities, it is mainly to be organized by the State organs and administrative law provisions; the latter is mainly a variety of legislative provisions on corporate law and self-employed persons, in addition also on institutions, social groups and ordinary citizens personal and other non-recurring provision of economic actors involved in some economic activity [2].

Legislation on economic subjects also includes the provisions of socio-economic structure within a country for the kind of economic subjects for which they reflect the overall composition and. In the modern market economy, the kind of economic entities are mainly determined by the objective requirements of the productive forces and economic development, be chosen by the market competition mechanism, countries generally recognized only by decree. But modern country also plays a certain dynamic regulation in this regard.

The legal provisions on each economic body and whole social-economic operation. Socio-economic activities and its overall economic activity run by a variety of socio-economic body composition. States must regulate the behavior of each subject, the development of various economic behavior rules. It includes a variety of economic management rules of conduct governing body of the national economy and on corporate social organizations and citizens of those basic rules are the management body of economic behavior. The former provisions general belong to the Organic Law of the state organs, administrative law and also needs some special provisions. The latter addition to a variety of corporate law and corporate law, contract law countries need to develop, market transactions law, unfair competition law, consumer protection law, etc; also includes the various aspects of national macro-control economic behavior of economic agents regulations, it is generally included in the plan law, investment law, tax law, financial law, foreign law, foreign trade law, etc.

The legal provisions on market and other external environment. In a market economy, the market is the central link in the national economy, but also the hub of national economic management. Complete with developed market system is the economic behavior of economic agents and the entire social economy are essential basic conditions. The types, distribution and development of markets are mainly decided by the economic development objective requirements. But the market is also inseparable from the modern state intervention and regulation. In China from a planned economy to a market economy, the country is responsible for the establishment and perfect of market. Need to develop various markets based on legislation, rules of the organization, activities and management, supervision and macro-control and other aspects.

Enterprises and other economic actors competing in the market and the fittest survived. The whole society will inevitably occur in some economic fluctuations and ups and downs. Countries need to develop a variety of social security law, the establishment and improvement of social security system, in order to reduce the burden on enterprises, making it more competitive, releasing some worries, and mitigating the effects of economic ups and downs to the society and people's lives [3].

The legal provisions on economic disputes and criminal law process. Content in this regard include reflecting on the previous three aspects related to the substantive law provisions and procedures law. In terms of procedural law, including the Criminal Procedure Law, Civil Procedure Law, Administrative Procedure Law and other judicial and administrative procedure law enforcement procedures and various arbitration law. These are also essential for a modern market economy legal protection mechanism.

The above four aspects in the modern market economy, legal system, every aspect of social and economic legislation contains both macroscopic and microscopic properties have legislation on various economic activities in the body; both adjust a variety of social relations among social equality body legislation, but also have to adjust to states party to the main body involved in the legal norms of national economic management relations; both on the state-owned economy, legislation, but also legislation on non-state-owned economy; both on the domestic economy legislation, but also legislation on foreign economic relations ; from the point of view of the national economy constituted authorities, both aspects of the legislation on planning, finance, taxation, finance and other functions 
of the national economy, legislation, but also in industry, agriculture, commerce, transportation, construction and other industry sectors; from National Economic activities (including national economic management activities) link point of view, it includes economic policy-making and economic organizations, the economy and economic disputes and other legislation dealing with illegal crime; legal norms applicable from the point of view of the degree of universality, some is always the guiding ideology, basic principles and policies, the basic principles and basic provisions of the national legal system to the socio-economic management, they are principled provisions of the various economic behavior of economic agents generally applicable, while others are on certain types of body specific provisions of an act. Modern market economy legal system is by the above various aspects of the social economy, sector, segment, legal norms factors are interrelated, and the composition of the interface between the organisms.

\section{The Suggestions to Improve the Socialist Market Economy Legal System}

Strengthen macro-control legislation. Modern market economy requires the state management of the social economy should focus on macro-control, while China is relatively weak in the past in this regard. Strengthen macro-control legislation, from the content of the legislation that includes the following main aspects:

The provisions on basic guiding ideology, objectives, principles, policies, basic principles and the basic legal system of national economy general structure and operation management (macro-control). In the past, the national macro-management of the economy to adapt to the prevailing economic system and socio-economic situation, and now the situation changes, adjustments need to be made larger. After the party's 14 Japan 8th National People's Congress held on the establishment and development of the socialist market economy, the basic guidelines and principles have been clear and recognized in the important documents of the Party and State, need to be standardized in the future legal form [4].

The provisions on the macro-control means and manners. In the past, there is a lack of experience in this area. We do not attach importance to full tax rates, interest rates, exchange rates and other economic leverage to regulate the economy; not good to play a guiding role of national plans and pricing policy; not good comprehensive use of various macro-control means, so as to achieve the country's macroeconomic organic complexes management objectives and intentions. Legislation in this area is not complete, especially in the strong need for improved content.

The provisions on the macro-control target. We should complete improve the national macro-control legislation on economic body and the socio-economic structure, the behavior of economic body and social economy, the market system and other external environment of. We should strengthen the control mechanisms of the state investment size, direction and structure of the law, in order to effectively control state investment and state-owned enterprises proper proportion and distributed throughout the social production and business structure.

Improve and complete the micro-economic legislation. The so-called micro-economic legislation refers to the legal provisions of the various economic activities in the body and its various economic behaviors. Due to a major shift taking place in the national economy, types and legal forms of economic activity subject to change, their economic activities in the field of economic relations and also change what happened, the management of each country and its economic behavior of economic agents, extent and information are also changing. Therefore, legislation in this regard in content and form must also be changed accordingly, "waste, change, legislation" arduous task.

Improve the civil legislation and strengthen administrative law provisions relating to economic management. Under the planned economy of the past based on public ownership situation long-established economic relations of citizens and legal principal of equality between these very underdeveloped, and therefore underdeveloped civil law. After the reforms, civil relations gradually developed and became important. The current national implementation of market economy, market regulation as the basic mechanism of social economic operation, civil law is the basic legal safeguards. Existing civil legislation, especially as the civil law of the Basic Law, only 156 of the 
Civil Code, has been seriously cannot meet the current civilian areas of activity is expanding and the need for new emerging civil relations. We should vigorously improve all kinds of civil legislations, and pay close attention to the development of a new Civil Code [5].

Establish and perfect the planning and steps of legal system. For the establishment and improvement of China's market economy legal system, the state legislature is required master plan. Plan includes steps and measures to achieve objectives and goals. The most important thing is to deepen our understanding of the legal system of the market economy, a thorough understanding of all aspects of the composition and structure of the various branches of law legal system, to understand the relationship among the various legal norms, to grasp the basic framework of the legal system in general that is target mode. Since the state has determined to establish a market economy, but in real life associated with the market economy large variety of social and economic relations are on the horizon, we have been able to basically see the development trend, coupled with foreign markets have a lot of experience to draw on economic legislation. Therefore, we can now proceed with the construction of China's market economy legal system building, without having the target pattern set aside pending the future blueprint.

\section{Conclusion}

Modern market economy requires a set of sound legal system. Since the reform and opening up, China attaches great importance to economic legislation. The economic and legal system frame adapting to the socialist market economic system is gradually forming, but there are many problems and contradictions, such as some laws and regulations with the traces of old economic system, economic legislation is seriously lagging behind with poor regulatory and operational, contents scattered with different standards and imbalances structures. Therefore, it is still a very important task to strengthen economic legislation and improve its quality.

\section{References}

[1] P.X.Gong, Contemporary Chinese market economy legal research, J. Nanjing University, 5(2007) 46-47.

[2] P. Jiang, The thinking of improving the market economy legal system, J. Chinese Law. 11(2006) 26-30.

[3] J.C. Shi, The socialist market economy and China Law, J. Chinese Law. 12(2009) 56-58.

[4] P.C. Xie, The basic structures of the market economy legal system, J. Legal Studies.9 (2009) $19-22$.

[5] Y.X. Zhang, Thoughts on building market economic system, J. Legal Studies. 4(2007) 129-132. 